\title{
The Peasant (Sedliak)
}

\author{
Author: František Švantner
}

First Published: 1947

Translations: Czech (in: Tvář v rose, 1966); Romanian (in: Joc omenesc, 1972); German (in: Die Dame und andere Erzählungen, 1976); Polish (in: Piargi, 1980); Russian (in: Izbrannoe, 1984).

Film Adaptation: V hodine strachu... (An Hour of Fear), TV film; screenplay Ján Medved' and Milan Rưžička, film director Milan Rưžička, premiered the 5th of November, 1968.

About the Author: František Švantner (1912-1950) was born in Bystrá in the Slovakian mountains Low Tatras. His works were often inspired by the highland region of the upper Hron river dominated by the peaks of Dumbier and Chopok. His father was a railway worker. Švantner graduated from the Teaching Institute and taught at schools near his birthplace. After the war, he worked in Matica slovenská and film studio in Banská Bystrica. He died prematurely of a brain tumour. Švantner's novels and short stories are considered to be the best works of Slovak literary Naturism (other authors of this were Margita Figuli, Lubo Ondrejov and Dobroslav Chrobák). Their rudimentary characters were placed in the settings of a primeval world of nature and mystery, and preferred irrational feelings. Sources of Naturism were folk magic tales, ideas of Friedrich Nietzsche or Henri Bergson and French regionalists (Giono, Ramuz, Pourrat). These works often stressed elementary narrative situations such as sensual love, friendship, fighting as well as death.

Further Important Publications: Malka (1942, Malka; short stories); Nevesta hôl'(1946, Upland Bride; novel); Život bez konca (A Life without End, posthumously, censored version 1956; original text 1974; novel); Dáma (The Dame, posthumously, 1966, edited by Ján Medved’ and Ján Števček; short stories).

\section{Content and Interpretation}

According to the context, the story is situated in the mountains of Slovakia during the winter of 1944/1945. All the figures are unnamed. In the foreground of the plot are a young peasant and his wife who live in a lonely cottage separated from the world. The married couple does not care about public events, they have only a vague idea of a terrible war going on somewhere in the east. Suddenly groups of armed men begin to appear in their mountains. At first some men (= partisans) "came without permission [...] to scare the peasant and his farm” (Švantner, 1976, p. 457). He has to provide food for them and their friends who stayed in the woods. Later the second group of soldiers (= Germans) settle in a nearby village. They do not want food, but they 
screamed at him, beat him, and searched his house and barn. They threaten to hang him when he supplies food to the first group. Nevertheless, the partisans return and take the food again.

The peasant hopes both groups of enemy soldiers will resolve their conflict in a fight and finally, his house will be quiet. However, in the night partisans bring an injured fellow and his little boy to the cottage. They order the peasant and his wife to take care of the wounded man and leave with the child giving them a precious ring as a compensation.

It turns out that the man is a doctor and a Jew. The peasant decides to take him to the hospital to get rid of him even as the wounded man begs him not to do so. The Jew even says, he has some hidden gold that he will give the peasant after the war. The peasant hitches horses to a wagon and goes to the hospital in the town. But the gate of the hospital is closed and a doctor declares there is no free bed there. Moreover, the wounded man calls out that he has lice and is hungry, and therefore they are harshly rejected.

The desperate and confused peasant believes that the Jew threatens his and his wife's lives. On the way back, a snow storm breaks out. The peasant takes the blanket and clothes off of the wounded Jew. Coming around a wayside shrine, the peasant is overcome with fear of sin and wraps the wounded man in his fur coat. When he returns home, he is convinced that the man is dead. He and his wife dig a grave for him, but they finally realise that the man is still alive. He even thanks the peasant for his help, because he has gotten rid of lice due to the cold. He is only hungry and wants to warm up. The peasant sends his wife to the cottage to prepare everything. When she returns, she sees her husband as he is filling up the grave. She begins to help him. The final sentence reads "That night, the peasant slept peacefully" (p. 478).

The whole plot of the story is narrated in hints. It is not said that the story is situated in the time of the Slovak National Uprising (see Jarunková's $\rightarrow$ A Black Solstice) when partisans are fighting with Germans. These episodes are perceived from the point of view of the peasant, who does not know the situation and sees everything from his naive mind. Similarly, it is not directly stated that the peasant kills the injured Jew, because the reader perceives this situation through the eyes of the peasant's wife.

\section{Main Topics and Film Adaptation}

The text was published for the first time in the review Slovenske pohlady in 1947, in book form posthumously in the extended edition of Švantner's collection Malka (1965). One year later, it was included in his collection of his short stories Dáma (1966, The Dame). The plot was based on a true story told by the author's friend, the evangelical pastor Štefan Kátlovský (Kuzmíková, 2012, p. 184).

The short prose with dramatic events and tragic end, situated in the remote mountains, has balladic features. Also a perspective of the naive narrator and some motifs 
like the golden ring (gold as a temptation) or the wayside shrine (Jesus Christ as betrayed and sacrificed like the injured Jew) belong to it.

Gold appears in connection with figures of the Jews in literature very often. Mostly it indicates their greed, desire for property. When the Jew offers his hidden gold to the peasant, the peasant refuses it: "The man wants to destroy him. [...] what insolence, could be life redeemed by gold?” (Švantner, 1976, p. 467).

Similarly in A Black Solstice, the Jewish woman offers money and gold for hiding her. However, while Berta Malatincová in A Black Solstice honestly rejects the payment of gold, here the peasant is secretly greedy for it.

The film version is more concrete (i.e. the main characters have names, Matúš and Pavlina), on the other hand some figures are depicted differently (i.e. the peasant is an older man) and also new scenes are added. The partisans take away the peasant's hens, the Germans confiscate one of his horses. The Germans behave more roughly. The peasant's wife wants to leave to the village, however, her husband decides to stay to protect his house and property. The biggest change comes at the end of the film. The Jew promises he will leave the next day at dawn. Unexpectedly the peasant sees that German soldiers accompanied by dogs are coming to his cottage. He assumes they are looking for the Jewish partisan. He hands him clothes and asks the Jew to flee. "You must leave." "I can't”, the Jew answers, "hide me somewere”. "For God's sake, leave, please”. The situation is very similar to the scene in Grosman's $\rightarrow$ The Shop on Main Street where Tono Brtko convinces Mrs Lautmanová to go out to the square and join the deportees in transport. The filmgoers can see, what happens later (killing of the Jew), only indirectly, from the face of the horrified woman. The German soldiers pass the cottage. After the wife finds out that her husband has killed the Jew, she desperately flees leaving him. So the film version stresses the inhumane behaviour of the peasant.

In the presentation of the Holocaust, Švantner's short story and even more its film version depict the Slovak peasant not as an innocent bystander or a Jews's helper. On the contrary, he becomes a guilty bystander which was unusual in Slovak literature, except for The Shop on Main Street. It is a paradox that at last, the peasant does not feel any guilt - although the statue of Jesus on the way home from the hospital seemed to revive his conscience. His animalistic, natural being does not know it. After killing the Jew he "slept peacefully".

\section{Cited Works}

Kuzmíková, J., ed. (2012). František Švantner: Život a dielo. Bratislava: Ústav slovenskej literatúry SAV. Švantner, F. (1976). Novely, ed. J. Medved’. Bratislava: Slovenský spisovatel, pp. 454-478.

\section{Further References}

Čepan, O. (1977). Kontúry naturizmu. Bratislava: Slovenský spisovatel'. Kuzmíková, J. (2000). František Švantner: V zákulisí naturismu. Bratislava: Veda, pp. 121-138. Kuzmí- 
ková, J. (2007). František Švantner - romantik, modernista alebo postmodernista?. In: F. Švantner, Nevesta hôl' a iné prózy. Bratislava: Kalligram, pp. 611-618. Števček, J. (1962). Baladická próza Františka Švantnera. Bratislava: Slovenský spisovatel', pp. 126-129. Števček, J. (1973). Lyrizovaná próza. Bratislava: Tatran, pp. 160-171. Šútovec, M. (2005). Mýtus a dejiny v próze naturizmu. Bratislava: Literárne informačné centrum. Szabó, M. (2020). Krčmár, upír, parazit. Premeny obrazu Žida v tvorbe Františka Švantnera zo čtyridsiatych rokov 20. storočia. Slovenská literatura, 67(4), pp. 331-344.

JH 